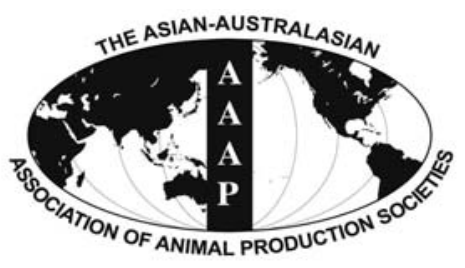

Asian-Aust. J. Anim. Sci.

Vol. 23, No. $1: 68$ - 73

January 2010

www.ajas.info

\title{
Mineral Retention in Young Broiler Chicks Fed Diets Based on Wheat, Sorghum or Maize
}

\author{
D. V. Thomas and V. Ravindran* \\ Institute of Food, Nutrition and Human Health, Massey University, Palmerston North, New Zealand
}

\begin{abstract}
The aim of the present study was to determine the changes in mineral retention of broiler chicks fed diets based on wheat, sorghum or maize during the first two weeks post-hatch. The retention of five major minerals (calcium, phosphorus, potassium, sodium and magnesium) and four trace minerals (iron, manganese, zinc and copper) was determined on days 3, 5, 7, 9 and 14 of age. The retention coefficients of individual minerals differed widely and the retention coefficients of major minerals were found to be considerably higher than those of trace minerals. Age effects were significant $(p<0.05)$ for all minerals. In general, mineral retention coefficients were highest at day 3 , declined to day 7, and remained unchanged to day 14 . Decline in mineral retention with age was similar on all three diets. The cereal effect was significant $(\mathrm{p}<0.05)$ for several minerals, with a general tendency for the sorghum-based diet to have greater retention than maize- or wheat-based diets. (Key Words : Broilers, Minerals, Cereals, Retention)
\end{abstract}

\section{INTRODUCTION}

Minerals are needed for all normal life processes and the physiological importance of minerals for farm animals, including poultry, is well documented (Spears, 1999; Underwood and Suttle, 1999). Recommendations for mineral requirements of poultry are available (NRC, 1994), but these are based on research with older strains and are inadequate and outdated for modern strains of poultry (Leeson, 2005). Despite the biological and economic importance, published data on the utilisation and retention of minerals in modern strains of poultry are limited. For this reason, in some cases, coefficients of mineral retention quoted for poultry are derived from values published for human infant liquid formulas (Ahmad and Sarwar, 2006).

Poultry derives the minerals required for normal growth and metabolism from the diet. The biological availability of a mineral from the diet is manifested by the efficiency with which the body utilises and retains the dietary mineral. The retention will be influenced by a number of dietary factors, including diet or ingredient type, source of minerals and, levels and relative proportions of various minerals. Published data on the effects of diet type, however, are

\footnotetext{
* Corresponding Author: V. Ravindran. Tel: +64-6-350-5528, Fax: +64-6-350-5684, E-mail: V.Ravindran@massey.ac.nz Received February 24, 2009; Accepted April 16, 2009
}

limited. To our knowledge, no previous study has compared the mineral retention for poultry of diets based on the three most commonly used cereal grains, namely, wheat, sorghum and maize.

The first two weeks after hatch is the most critical period in the life of broiler chickens. While the utilisation of energy and amino acids by young chicks has received some attention (Zelenka, 1968; Batal and Parsons, 2002, 2004), studies on the changes in retention of minerals with age are scanty. A better understanding of mineral retention by the young chicks is necessary if diets are to meet the requirements of the chick during this critical stage of development. To assess the significance of developmental changes in mineral utilisation in the newly hatched broiler chicken, it is necessary to obtain accurate data on mineral retention over the total tract as the absorption of some minerals appears to continue in the hindgut of poultry (Ravindran et al., 2006). Furthermore, increasing awareness of the environmental cost of waste disposal in recent years is placing more emphasis on minimising excessive dietary mineral levels (Paik, 2001; Selle and Ravindran, 2007).

The study reported herein was undertaken to determine the influence of diet type on the retention of selected major (calcium (Ca), phosphorus (P), sodium $(\mathrm{Na})$, potassium $(\mathrm{K})$ and magnesium $(\mathrm{Mg})$ ) and trace (copper $(\mathrm{Cu})$, manganese $(\mathrm{Mn})$, zinc ( $\mathrm{Zn})$ and and iron (Fe)) minerals by the broiler chick during the first two weeks post-hatch. 


\section{MATERIALS AND METHODS}

\section{Diets}

Three dietary treatments based on wheat, sorghum or maize were formulated to have similar levels of metabolisable energy, amino acids, calcium and available phosphorus (Table 1). The diets were formulated to meet or exceed the NRC (1994) requirements for all nutrients. The wheat-based diet was supplemented with a commercial xylanase as this is standard commercial practice and necessary if the research results are to have practical relevance. All diets were cold pelleted at $60^{\circ} \mathrm{C}$.

\section{Experimental procedures}

Day-old male broilers (Ross 308) were weighed and allocated to 18 cages of eight chicks each. Each dietary treatment was then assigned to six replicate cages. The chicks were housed in stainless steel brooder cages, with facilities for excreta collection, in an environmentally controlled room. Temperature was maintained at $32^{\circ} \mathrm{C}$ on day 1 decreasing to $27^{\circ} \mathrm{C}$ on day 14 . Feed and water were available at all times. On days 3, 5, 7, 9 and 14, feed intake was accurately measured and total excreta were collected over a 24-h period using polythene sheets in collection trays. A sample of feed was taken daily to measure any moisture loss and this was used to correct feed intake. Excreta were accurately weighed, mixed in a blender and representative samples obtained per cage.

\section{Chemical analysis}

Excreta samples were freeze-dried and, diet and dried excreta samples ground to pass through a $1.0 \mathrm{~mm}$ sieve and stored in airtight plastic containers until chemical analysis. Dry matter (AOAC, 2005) and mineral contents were determined in the diet and excreta samples. The samples were wet acid digested with nitric and perchloric acid mixture, and concentrations of $\mathrm{Ca}, \mathrm{P}, \mathrm{Na}, \mathrm{K}, \mathrm{Mg}$ and $\mathrm{Fe}$ were determined at specific wavelengths for each element by an Inductively Coupled Plasma-Optical Emission Spectroscopy (ICP-OES) using a Thermo Jarrell Ash IRIS instrument (Thermo Jarrell Ash Corporation, Franklin, MA). The instrument was calibrated against standards (Junsei Chemical Co., Ltd., Tokyo, Japan) of known concentration. The concentrations of $\mathrm{Cu}, \mathrm{Mn}$ and $\mathrm{Zn}$ were determined by Inductively Coupled Plasma-Mass Spectrometry (ICP-MS) using a Perkin Elmer Elan 6000 instrument.

\section{Calculations}

The total tract retention coefficient of minerals was calculated using the following formula, with appropriate corrections for differences in dry matter content.
Table 1. Composition and calculated analysis $(\mathrm{g} / \mathrm{kg})$ of diets based on wheat, sorghum and maize

\begin{tabular}{|c|c|c|c|}
\hline Ingredient & Wheat diet & Sorghum diet & Maize diet \\
\hline Wheat & 657.6 & - & - \\
\hline Sorghum & - & 610.8 & - \\
\hline Maize & - & - & 586.2 \\
\hline Soybean meal & 273.4 & 321.9 & 351.8 \\
\hline Soybean oil & 27.3 & 20.9 & 17.8 \\
\hline Dicalcium phosphate & 20.3 & 19.1 & 21.7 \\
\hline Limestone & 3.4 & 9.4 & 7.8 \\
\hline Salt & 1.4 & 1.6 & 2.3 \\
\hline Lysine $\cdot \mathrm{HCl}$ & 3.4 & 2.9 & 1.8 \\
\hline DL-methionine & 2.4 & 3.3 & 2.5 \\
\hline L-threonine & 1.2 & 0.8 & 0.3 \\
\hline Sodium bicarbonate & 3.6 & 3.3 & 1.8 \\
\hline Trace mineral premix ${ }^{1}$ & 2.5 & 2.5 & 2.5 \\
\hline Vitamin premix ${ }^{2}$ & 0.5 & 0.5 & 0.5 \\
\hline Xylanase $^{3}$ & + & - & - \\
\hline \multicolumn{4}{|l|}{ Calculated analysis } \\
\hline AME (MJ/kg) & 12.5 & 12.5 & 12.5 \\
\hline Crude protein & 22.0 & 22.0 & 22.0 \\
\hline Lysine & 1.35 & 1.35 & 1.35 \\
\hline Methionine+cystine & 0.95 & 0.95 & 0.95 \\
\hline Calcium & 0.95 & 0.95 & 0.95 \\
\hline Available phosphorus & 0.48 & 0.48 & 0.48 \\
\hline
\end{tabular}

${ }^{1}$ Supplied (as inorganic salts) per kg diet: Mn, $125 \mathrm{mg} ; \mathrm{Zn}, 60 \mathrm{mg}$; Cu, 3 mg; Mo, 0.5 mg; Co, 0.3 mg; I, 1.0 mg; Fe, 25 mg; Se, 200 g; choline chloride, $638 \mathrm{mg}$.

${ }^{2}$ Supplied per kg diet: trans-retinol, $3.33 \mathrm{mg}$; cholecalciferol, 60 $\mu \mathrm{g}$; dl$\propto$-tocopheryl acetate, $60 \mathrm{mg}$; menadione, $4 \mathrm{mg}$; thiamine, $3.0 \mathrm{mg}$; riboflavin, $12 \mathrm{mg}$; calcium pantothenate, $12.8 \mathrm{mg}$; niacin, $35 \mathrm{mg}$; pyridoxine, $10 \mathrm{mg}$; folic acid, $5.2 \mathrm{mg}$; cyanocobalamin, $0.017 \mathrm{mg}$; biotin, $0.2 \mathrm{mg}$; antioxidant, $100 \mathrm{mg}$.

${ }^{3}$ Kemzyme, Kemin Industries, Singapore.

Retention coefficient

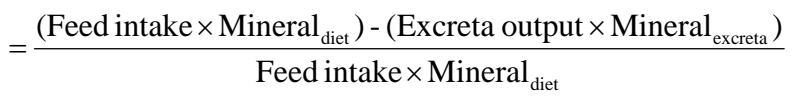

where mineral $_{\text {diet }}=$ mineral content in diet and mineral $l_{\text {excreta }}$ $=$ mineral content in excreta.

In these calculations, it was assumed that the feed intake recorded over the 24-h period completely coincided with the excreta output over this period. However, this assumption may not be totally correct as it is known that feed intake may increase by up to $10 \%$ daily in young broilers, which may result in slight overestimation of the retention of minerals. 
Table 2. Determined mineral contents of diets based on wheat, sorghum and maize

\begin{tabular}{lccc}
\hline Mineral & Wheat-based diet & Sorghum-based diet & Maize-based diet \\
\hline Calcium (g/kg) & 9.8 & 10.7 & 11.5 \\
Phosphorus (g/kg) & 7.8 & 7.2 & 8.4 \\
Potassium (g/kg) & 9.7 & 9.4 & 10.6 \\
Sodium (g/kg) & 2.0 & 1.8 & 2.1 \\
Magnesium (g/kg) & 2.0 & 1.9 & 2.0 \\
Iron (mg/kg) & 203 & 189 & 239 \\
Manganese (mg/kg) & 163 & 148 & 174 \\
Zinc (mg/kg) & 156 & 150 & 158 \\
Copper (mg/kg) & 25 & 28 & 21 \\
\hline
\end{tabular}

\section{Data analysis}

The data were subjected to repeated measures analysis using the General Linear Models procedure (SAS, 1997) to assess diet type differences over age and diet typexage interactions. When a significant F-test was detected, means were separated using the least significant difference test.

\section{RESULTS}

The determined mineral contents of the diets are shown in Table 2. The mineral contents in the three diet types are similar, except for Ca. The Ca content of the wheat-based diet was lower than those in sorghum- and maize-based diets.

The total tract mineral retention of major minerals in young broilers from days 3 to 14 post-hatch is presented in
Table 3. The retention for individual minerals differed widely, ranging from 0.24 for $\mathrm{Mg}$ to 0.64 for Na on day 14 . A notable finding was the very high $(>92 \%)$ retention of $\mathrm{Na}$ on day 3. Age effects were significant $(p<0.05)$ for all minerals, with retention being highest on day 3 . The exception was $\mathrm{Ca}$ where the highest retention was observed on day 5 . In general mineral retention declined from day 3 to day 7 after which no changes were observed to day 14 . Decline in mineral retention with age was similar across all three diets, as shown by non-significant $(\mathrm{p}>0.05)$ diet typex age interaction.

Diet type effect was significant $(\mathrm{p}<0.05)$ for Ca retention on day 3, for $\mathrm{Mg}$ on day 5, for $\mathrm{P}$ on all days except day 14 and for Na on all days except day 3. Retention of $\mathrm{K}$ was not different $(\mathrm{p}>0.05)$ between the diet types. In general, mineral retention in sorghum diets was found to be

Table 3. Total tract retention of major minerals in broilers fed wheat, sorghum and maize-based diets during the first 14 days post-hatch

\begin{tabular}{|c|c|c|c|c|c|c|c|}
\hline \multirow{2}{*}{ Mineral } & \multirow{2}{*}{ Diet } & \multicolumn{5}{|c|}{ Day } & \multirow{2}{*}{ Pooled SEM } \\
\hline & & 3 & 5 & 7 & 9 & 14 & \\
\hline \multirow[t]{3}{*}{ Calcium } & Wheat & $0.39^{\mathrm{a}, 12}$ & $0.47^{3}$ & $0.35^{1}$ & $0.41^{2}$ & $0.44^{23}$ & \\
\hline & Sorghum & $0.51^{\mathrm{D}, 12}$ & $0.55^{2}$ & $0.52^{12}$ & $0.50^{12}$ & $0.49^{1}$ & 0.021 \\
\hline & Maize & $0.43^{\mathrm{a}}$ & 0.45 & 0.40 & 0.42 & 0.40 & \\
\hline \multirow[t]{3}{*}{ Phosphorus } & Wheat & $0.59^{\mathrm{a}, 3}$ & $0.54^{\mathrm{a}, 3}$ & $0.44^{\mathrm{a}, \mathrm{I}}$ & $0.47^{\mathrm{a}, 12}$ & $0.50^{2}$ & \\
\hline & Sorghum & $0.66^{\mathrm{D}, 3}$ & $0.60^{\mathrm{b}, 2}$ & $0.54^{\mathrm{D}, 1}$ & $0.52^{\mathrm{D}, 1}$ & $0.53^{1}$ & 0.016 \\
\hline & Maize & $0.60^{\mathrm{a}, \mathrm{s}}$ & $0.55^{\mathrm{a}, \mathrm{L}}$ & $0.47^{\mathrm{a}, 1}$ & $0.49^{\mathrm{ab}, 1}$ & $0.49^{1}$ & \\
\hline \multirow[t]{3}{*}{ Potassium } & Wheat & $0.47^{2}$ & $0.35^{1}$ & $0.30^{1}$ & $0.32^{1}$ & $0.32^{1}$ & \\
\hline & Sorghum & $0.47^{3}$ & $0.37^{2}$ & $0.30^{1}$ & $0.34^{12}$ & $0.30^{1}$ & 0.021 \\
\hline & Maize & $0.49^{3}$ & $0.38^{2}$ & $0.34^{12}$ & $0.35^{12}$ & $0.30^{11}$ & \\
\hline \multirow[t]{3}{*}{ Sodium } & Wheat & $0.92^{3}$ & $0.58^{\mathrm{a}, 12}$ & $0.54^{\mathrm{a}, \mathrm{1}}$ & $0.56^{\mathrm{a}, 12}$ & $0.60^{\mathrm{a}, \angle}$ & \\
\hline & Sorghum & $0.93^{3}$ & $0.67^{\mathrm{D}, L}$ & $0.61^{\mathrm{D}, 1}$ & $0.62^{\mathrm{D}, 1}$ & $0.65^{\mathrm{D}, 12}$ & 0.017 \\
\hline & Maize & $0.95^{2}$ & $0.68^{\mathrm{b}, 1}$ & $0.66^{\mathrm{D}, 1}$ & $0.63^{\mathrm{D}, 1}$ & $0.68^{\mathrm{D}, 1}$ & \\
\hline \multirow[t]{3}{*}{ Magnesium } & Wheat & $0.34^{2}$ & $0.25^{\mathrm{a}, 1}$ & $0.21^{1}$ & $0.24^{1}$ & $0.24^{1}$ & \\
\hline & Sorghum & $0.39^{5}$ & $0.33^{\mathrm{D}, \angle \mathrm{s}}$ & $0.26^{1}$ & $0.27^{12}$ & $0.24^{1}$ & 0.024 \\
\hline & Maize & $0.39^{2}$ & $0.29^{\mathrm{ab}, 1}$ & $0.26^{1}$ & $0.27^{1}$ & $0.23^{1}$ & \\
\hline
\end{tabular}

$\overline{{ }^{a, 0} \mathrm{D}}$ Within each mineral, different superscript letters within a column are statistically different $(\mathrm{p}<0.05)$

${ }^{1,2,3}$ Different superscript numbers within a row are statistically different $(\mathrm{p}<0.05)$. 
greater than those in maize- and wheat-based diets. Another notable observation was the lower $(\mathrm{p}<0.05)$ Na retention in wheat-based diets compared to those in the other two diet types.

The total tract retention of trace minerals in young broilers is shown in Table 4. Retention coefficients of the trace minerals were determined to be considerably lower than those determined for major minerals. Of particular interest was that the retention coefficient of $\mathrm{Zn}$ was close to zero on day 14. Age effects were significant $(\mathrm{p}<0.05)$ for all trace minerals, with retention being highest at day 3 , declining to day 5 and then remaining unchanged to day 14 . Diet typexage interaction was not significant $(p>0.05)$ for any trace mineral, indicating that the changes in retention with age was similar, irrespective of diet type.

Diet type effects were significant $(p<0.05)$ for $\mathrm{Fe}$ retention from day 7 onwards, for $\mathrm{Mn}$ and $\mathrm{Zn}$ till day 7 and for $\mathrm{Cu}$ on all days except day 9. The notable observations were the lower retention of $\mathrm{Fe}$ and higher retention of $\mathrm{Cu}$ in sorghum-based diets, and the lower $\mathrm{Cu}$ retention in maizebased diets.

\section{DISCUSSION}

No published data are available on the pattern of mineral retention over the first 14 days of age in broiler chickens. However, some studies have shown a decrease in the apparent metabolisable energy over the first several days post-hatch, followed by an increase after the first week (Zelenka, 1968; Murakami et al., 1992; Thomas et al., 2008); In general, the mineral retention data showed a similar pattern, with the highest retention coefficients being observed at 3-5 days, declining thereafter to day 7 post- hatch and then remaining unchanged to day 14 . However, in contrast to those observed in apparent metabolisable energy, no differences in retention were noted between days 7 and 14 of age. In the newly hatched chick, the yolk sac is the primary contributor to the overall nutrition during the first few days of life and the presence of yolk appears to have a beneficial effect on mineral retention, as indicated by the high retention coefficients on day 3 . The subsequent drop in mineral retention may reflect the loss of this yolk sac effect. In addition, the digestive tract of the newly hatched chick is sterile and is rapidly colonised by microflora after hatching. The changing gut microflora may contain bacterial species which may lower availability by competing for minerals and it is possible that these effects may also contribute, at least in part, to the subsequent drop in mineral retention.

Studies reporting retention coefficients for a range of minerals in poultry are scanty and, to the authors' knowledge, no published data are available for young birds. The exceptions are the retention of $\mathrm{Ca}$ and $\mathrm{P}$ for which, because of increasing interest in phytase research, wealth of data have become available for older birds. The retention coefficients of around 0.45 for $\mathrm{Ca}$ and 0.50 for $\mathrm{P}$ determined in the current study for 14-day old broilers is comparable to those generally reported in the phytase literature for 21-day old broilers (Selle and Ravindran, 2007). Ravindran et al. (2006) determined the ileal digestibility and total tract retention of a number of minerals for 21-day old broiler chickens. The major differences between ileal digestibility and retention coefficients are method of determination (marker vs. total excreta collection) and site of determination (ileal vs. excreta). Data from their study showed ileal digestibility and total tract retention coefficients were similar for $\mathrm{Ca}, \mathrm{P}, \mathrm{Fe}$ and $\mathrm{Mn}$, lower

Table 4. Total tract retention of trace minerals in broilers fed wheat, sorghum and maize-based diets during the first 14 days post-hatch

\begin{tabular}{|c|c|c|c|c|c|c|c|}
\hline \multirow{2}{*}{ Mineral } & \multirow{2}{*}{ Diet } & \multicolumn{5}{|c|}{ Day } & \multirow{2}{*}{ Pooled SEM } \\
\hline & & 3 & 5 & 7 & 9 & 14 & \\
\hline \multirow[t]{3}{*}{ Iron } & Wheat & $0.26^{2}$ & $0.20^{2}$ & $0.11^{\mathrm{a}, 1}$ & $0.19^{\mathrm{ab}, 12}$ & $0.21^{\mathrm{b}, 2}$ & \\
\hline & Sorghum & $0.27^{3}$ & $0.19^{23}$ & $0.11^{\mathrm{a}, 12}$ & $0.12^{\mathrm{a}, 1}$ & $0.06^{\mathrm{a}, 1}$ & 0.029 \\
\hline & Maize & $0.34^{2}$ & $0.20^{1}$ & $0.21^{\mathrm{b}, 1}$ & $0.24^{\mathrm{b}, 1}$ & $0.21^{\mathrm{b}, 1}$ & \\
\hline \multirow[t]{3}{*}{ Manganese } & Wheat & $0.17^{\mathrm{a}, 2}$ & $0.11^{\mathrm{a}, 1}$ & $0.09^{\mathrm{a}, 1}$ & $0.08^{1}$ & $0.08^{1}$ & \\
\hline & Sorghum & $0.32^{\mathrm{b}, 3}$ & $0.24^{\mathrm{b}, 23}$ & $0.31^{\mathrm{b}, 2}$ & $0.11^{1}$ & $0.13^{12}$ & 0.046 \\
\hline & Maize & $0.25^{\mathrm{ab}, 2}$ & $0.13^{\mathrm{ab}, 12}$ & $0.11^{\mathrm{a}, 1}$ & $0.17^{12}$ & $0.11^{1}$ & \\
\hline \multirow[t]{3}{*}{ Zinc } & Wheat & $0.24^{\mathrm{a}, 3}$ & $0.10^{\mathrm{a}, 2}$ & $0.08^{\mathrm{a}, 12}$ & $0.08^{12}$ & $-0.01^{1}$ & \\
\hline & Sorghum & $0.43^{\mathrm{b}, 3}$ & $0.25^{\mathrm{b}, 2}$ & $0.21^{\mathrm{b}, 2}$ & $0.11^{1}$ & $0.05^{1}$ & 0.036 \\
\hline & Maize & $0.28^{\mathrm{a}, 3}$ & $0.13^{\mathrm{a}, 2}$ & $0.10^{\mathrm{a}, 2}$ & $0.13^{2}$ & $0.00^{1}$ & \\
\hline \multirow[t]{3}{*}{ Copper } & Wheat & $0.31^{\mathrm{b}, 2}$ & $0.19^{\mathrm{a}, 1}$ & $0.18^{\mathrm{b}, 1}$ & $0.18^{1}$ & $0.21^{\mathrm{b}, 1}$ & \\
\hline & Sorghum & $0.50^{c, 3}$ & $0.44^{\mathrm{b}, 23}$ & $0.40^{c, 2}$ & $0.31^{1}$ & $0.38^{\mathrm{c}, 2}$ & 0.029 \\
\hline & Maize & $0.23^{\mathrm{a}, 3}$ & $0.12^{\mathrm{a}, 12}$ & $0.08^{\mathrm{a}, 12}$ & $0.09^{12}$ & $0.04^{\mathrm{a}, 1}$ & \\
\hline
\end{tabular}

\footnotetext{
a, b, c Within each mineral, different superscripts letters within a column are statistically different $(\mathrm{p}<0.05)$.
}

${ }^{1,2,3}$ Different superscript numbers within rows are statistically different $(\mathrm{p}<0.05)$. 
retention coefficients for $\mathrm{K}$ and $\mathrm{Zn}$, and higher retention coefficients for $\mathrm{Mg}, \mathrm{Cu}$ and $\mathrm{Na}$. In particular, the retention coefficient was considerably higher (0.68) than the ileal digestibility coefficient $(-0.30)$ for $\mathrm{Na}$, suggesting that significant re-absorption of $\mathrm{Na}$ is taking place in the hindgut of chickens.

No obvious explanations can be provided for the differences observed in the retention of some minerals in different diet types. These include the lower retention of $\mathrm{Na}$ in wheat-based diets, lower retention of $\mathrm{Fe}$ and higher retention of $\mathrm{Cu}$ in sorghum-based diets, and lower retention of $\mathrm{Cu}$ in maize-based diets.

Trace minerals are usually supplied in commercial poultry diets as inorganic trace mineral salts (oxides or sulphates). However, it is known that the bioavailability of inorganic trace minerals can be low and variable due to an array of nutritional antagonisms, including dietary levels of phytic acid, fibre, Ca and P (Ravindran et al., 1995; Underwood and Suttle, 1999; Leeson, 2005). This may explain the very poor retention of trace minerals determined for $\mathrm{Mn}$ and $\mathrm{Zn}$ in the current study. Given the biological importance of these minerals in growth and metabolism, there data highlight the need to improve their retention in young birds.

Overall, the present findings showed that the retention of minerals, especially of trace minerals, in young broilers is low. This also has implications for the excretion of minerals into the environment, which is becoming a worldwide issue. At the same time, the low retention provides opportunities for dietary manipulation to improve utilisation of minerals. In this context, the use of microbial phytases and trace mineral chelates may be relevant. The use of exogenous phytase is now a widespread commercial practice to improve the bioavailability of $\mathrm{P}, \mathrm{Ca}$, energy and amino acids in broiler diets (Paik, 2003; Selle et al., 2003 a,b; Selle et al., 2007; Selle and Ravindran, 2007). In addition, supplemental phytase has also been shown to improve the utilisation of $\mathrm{Mg}, \mathrm{Cu}, \mathrm{Mn}$ and $\mathrm{Zn}$ (Viveros et al., 2002; Ravindran et al., 2006). Compared to inorganic sources, chelates of $\mathrm{Zn}, \mathrm{Cu}$ and $\mathrm{Mn}$ have been shown to confer stability in the upper digestive tract, thereby avoiding binding with antagonists and improving bioavailability (Paik, 2001; Leeson, 2005; Lim et al., 2006; Bao and Choct, 2009). The use of organic sources along with microbial phytase may provide even greater mineral retention (Swiatkiewicz et al., 2001), allowing the requirements of birds to be met with lower mineral levels in diets.

In conclusion, the present study characterised the changes in the retention of minerals in newly hatched chick during the first two weeks of life. In particular, the data highlighted the poor availability of trace minerals from inorganic sources to young chicks and the decline in mineral retention with age, irrespective of diet type. Meeting the mineral requirements of the newly hatched chick is important in modern broiler management. It is hoped that accurate data on mineral retention over this critical period will help to define mineral requirements and assist in the formulation of appropriate diets for chicks over the first two weeks post-hatch.

\section{REFERENCES}

AOAC. 2005. Official methods of analysis of AOAC International, Association of Official Analytical Chemists. $18^{\text {th }}$ Edition. Gaithersburg, MD.

Ahmad, T. and M. Sarwar. 2006. Dietary electrolyte balance: implications in heat stressed broilers. Worlds Poult. Sci. J. 62: 638-653.

Bao, Y. M. and M. Choct. 2009. Trace mineral nutrition for broiler chickens and prospects of application of organically complexed trace minerals: a review. Anim. Prod. Sci. 49:269282.

Batal, A. B. and C. M. Parsons. 2002. Effects of age on nutrient digestibility in chicks fed different diets. Poult. Sci. 81:400407.

Batal, A. B. and C. M. Parsons. 2004. Utilization of various carbohydrate sources as affected by age in the chick. Poult. Sci. 83:1140-1147.

Leeson, S. 2005. Trace mineral requirements of poultry-Validity of NRC recommendations. In: Re-defining mineral nutrition (Ed. J. A. Taylor-Pickard and L. A. Tucker). Nottingham University Press, Nottingham, UK. pp. 107-117.

Lim, H. S., I. K. Paik, T. I. Sohn and W. Y. Kim. 2006. Effects of supplementing copper chelates in the form of methionine. Chitosan and yeast on the performance of broilers. Asian-Aust. J. Anim. Sci. 19:1322-1327.

Murakami, H., Y. Akiba and M. Horiguchi. 1992. Growth and utilization of nutrients in newly-hatched chick with or without removal of residual yolk. Growth Dev. Aging. 56:75-84.

NRC. 1994. Nutrient requirements of domestic animals. Nutrient Requirements of Poultry, 9th rev. ed., National Research Council, National Academy Press, Washington DC.

Paik, I. K. 2001. Management of excretion of phosphorus, nitrogen and pharmacological level minerals to reduce environmental pollution from animal production - A review. Asian-Aust. J. Anim. Sci. 14:384-394.

Paik, I-K. 2003. Application of phytase, microbial or plan origin, to reduce phosphorus excretion in poultry production. AsianAust. J. Anim. Sci. 16:124-135.

Ravindran, V., W. L. Bryden and E. T. Kornegay. 1995. Phytates: occurrence, bioavailability and implications in poultry nutrition. Poult. Avian Biol. Rev. 6:125-143.

Ravindran, V., P. C. H. Morel, G. G. Partridge, M. Hruby and J. S. Sands. 2006. Influence of Escherichia coli-derived phytase on nutrient utilization in broiler starters fed diets containing varying concentrations of phytic acid. Poult. Sci. 85:82-89.

SAS. 1997. SAS/STAT ${ }^{\circledR}$ User's Guide: Statistics. Version 6.12. SAS Institute Inc., Cary, NC.

Selle, P. H. and V. Ravindran. 2007. Microbial phytase in poultry nutrition. Anim. Feed Sci. Technol. 135:1-41. 
Selle, P. H., V. Ravindran, P. H. Pittolo and W. L. Bryden. 2003a. Effect of phytase supplementation of diets, with two tiers of nutrient specifications, on growth performance and protein efficiency ratios of broiler chickens. Asian-Aust. J. Anim. Sci. 16:1158-1164.

Selle, P. H., V. Ravindran, G. Ravindran, P. H. Pittolo and W. L. Bryden. 2003b. Influence of phytase and xylanase supplementation on the performance and nutrient utilisation of broilers fed wheat-based diets. Asian-Aust. J. Anim. Sci. 16: 394-402.

Selle, P. H., V. Ravindran, G. Ravindran and W. L. Bryden. 2007. Effects of dietary lysine and microbial phytase on growth performance and nutrient utilisation of broiler chickens. AsianAust. J. Anim. Sci. 20:1100-1108.

Spears, J. W. 1999. Re-evaluation of the metabolic essentiality of the minerals (A review). Asian-Aust. J. Anim. Sci. 12:10021008.
Swiatkiewicz, S., J. Koreleski and D. Zhong. 2001. The bioavailability of zinc from inorganic and organic sources in broiler chickens as affected by addition of phytase. J. Anim. Feed Sci. 10:317-328.

Thomas, D. V., V. Ravindran and G. Ravindran. 2008. Nutrient utilisation of diets based on wheat, sorghum or maize by the newly hatched broiler chick. Br. Poult. Sci. 49:429-435.

Underwood, E. J. and N. F. Suttle. 1999. The mineral nutrition of livestock. $3^{\text {rd }}$ ed. CABI Publishing, New York, NY.

Viveros, A., A. Brenes, I. Arija and C. Centenot. 2002. Effects of microbial phytase supplementation on mineral utilisation and serum enzyme activities of broiler chicks fed different levels of phosphorus. Poult. Sci. 81:1172-1183.

Zelenka, J. 1968. Influence of the age of chickens on the metabolisable energy values of poultry diets. Br. Poult. Sci. 9: 135-142. 